Research Article

\title{
Bovine Tuberculosis (bTB)-Isolation and Species-Specific Identifica- tion of Mycobacterium bovis from Bovine Raw Milk in Pakistan
}

\section{Asad Ullah ${ }^{1 *}$, Umar Sadique ${ }^{2}$, Sultan Ayaz ${ }^{1}$, Muhammad Subhan Qureshi ${ }^{2}$ and Farhan Anwar Khan ${ }^{2}$}

${ }^{1}$ College of Veterinary Sciences and Animal Husbandry, Abdul Wali Khan University, Mardan, Pakistan; ${ }^{2}$ College of Veterinary Sciences, Faculty of Animal Husbandry and Veterinary Sciences, The University of Agriculture, Peshawar, KPK, Pakistan.

Abstract $\mid$ A research study was carried out to investigate the prevalence of bovine tuberculosis (bTB); detection of Mycobacterium bovis (M. bovis) infection in lactating indigenous cattle/buffaloes raised on different commercial dairy farms and exposing the hazards linked with milk-born tuberculosis infection in the area where unpasteurized milk is normally used in the central zone of Khyber Pakhtunkhwa (KP), Pakistan. A total of 1225 cattle and 1175 buffaloes of more than one year were studied for the prevalence of bovine tuberculosis. A total of 1608 milk samples (793 from cattle and 815 from buffaloes) were collected from already PPD (purified protein derivatives) tested lactating animals aseptically. The data obtained were finally analyzed statistically using chi squared test. The Mycobacterium was identified through ZN staining, culture and PCR. Out of 1608 milk samples, 60 (3.73\%) were found positive for acid fast bacteria through $\mathrm{ZN}$ staining whereas the prevalence of Mycobacterium bovis was confirmed in 65 (4.04\%) and 85 (5.29\%) isolates through culture and PCR respectively. The zoonotic spread of $M$. bovis infection was established in the study area. The data determines that animal food products in Pakistan are common reservoirs of mycobacteria and may pose great risk to the public. Bovine tuberculosis (bTB) is found one of the neglected zoonotic disease (NZD) caused by Mycobacterium bovis with public health significance and appear as a life threatening infection at the human-animal-ecosystem interface in low-resource settings in the central zone of KP, Pakistan. The surveillance, prevention and control programs of this NZD in the KP province of Pakistan is necessary because of the continual unrestricted movement of infected animals and the use of unpasteurized milk which might result in an increased spread of bTB to human population.

Received | December 11, 2019; Accepted | March 18, 2020; Published | April 25, 2020

*Correspondence | Asad Ullah, College of Veterinary Sciences and Animal Husbandry, Abdul Wali Khan University Mardan, Pakistan; Email: asadullah@awkum.edu.pk

Citation | Ullah, A., U. Sadique, S. Ayaz, M.S. Qureshi and F.A. Khan.2020. Bovine tuberculosis (bTB)-isolation and species-specific identification of Mycobacterium bovis from bovine raw milk in Pakistan. Sarbad Journal of Agriculture, 36(2): 489-498.

DOI | http://dx.doi.org/10.17582/journal.sja/2020/36.2.489.498

Keywords | Bovine tuberculosis, Mycobacterium bovis, Raw milk, PCR, Pakistan

\section{Introduction}

$\mathrm{T}$ uberculosis (TB) is a chronic infectious disease of both human and animals. Mycobacterium tuberculosis (M. tuberculosis) is the etiological agent of TB in human (Olea-Popelka et al., 2017) while Mycobacterium bovis (M. bovis) causing TB in animals (Grange, 1998) commonly called bovine tuberculosis (bTB). Bovine tuberculosis is one of the multifaceted, stubborn and debatable problems in front of world 
cattle industry with estimations of huge economic loses annually (Brooks-Pollock et al., 2014). Mycobacterium bovis and $M$. tuberculosis are identical both genetically and antigenically and cause similar clinical disease in humans (Danker et al., 1993; Grange et al., 1994). Globally, human tuberculosis is caused by Mycobacterium tuberculosis and bovine tuberculosis (bTB) is caused by Mycobacterium bovis. Bovine tuberculosis is a disease of dairy animals (Jalil et al., 2003). The diseases that are transmitted from animals (vertebrates) to humans are called zoonoses. In human, majority of newly emerging infections are of zoonotic origin (Quammen, 2012). Most zoonoses occure during preparation of infected meat and ingestion or close contact to animals duing hunting, herding or slaughtering animals (Karesh et al., 2012). Transmission of Mycobacterium bovis occurs either inhalation or oral route (Winthrop et al.,2005). All the developed countries have been succeeded in reducing the transmission of TB in humans with the help of proper pasteurization of dairy products and proper control of bTB infection in bovines (Michel et al., 2010; Torgerson and Torgerson, 2008). Although TB in humans is significant zoonotic-infection reported globally wherever bTB is widespread and improper milk pasteurization and other dairy products (Moda et al., 1996). Still, the significant confirmation of $M$. bovis infection in human beings as the etiology of zoonotic tuberculosis might be took too lightly (OleaPopelka et al., 2017). The trials and apprehensions were found the same as stated 15 years ago as showed from the findings of a study on global zoonotic tuberculosis in 2013. In current years, the scientific consideration and resources assigned to the problems of human beings infected with $M$. bovis might not be related comparatively allocated to other diseases. The significant reassessment of $M$. bovis infection in the human population is mandatory in areas where bTB is endemic and where human-animal co-habitation favor the transmission of $M$. bovis to the people living around. The movement of infected animals from one place to another, reinfection from ecological factors/ reservoirs along with poor sensitivity of investigative tools have considerable role in the transmission of bovine tuberculosis between-farm and within-farm (Brooks-Pollock et al., 2014). In view of WHO's end TB strategy recommended by the WHO Member States Health Authorities in 2014 to achieve a world free of TB by 2035 as nations move towards identifying around 3 million TB cases expected to be missed annually. We request all TB stakeholders to deed to perfectly diagnose and treat $M$. bovis infection in human population (Olea-Popelka et al., 2017). Animals affected by tuberculosis loses their productive efficacy by $10-25 \%$ (Hussain and Rabbani, 2000; Radostits et al., 2000). Quick finding, suitable treatment and contact location are the key factors in the control of TB to arrest further transmission of the infection (Broekmans,1994). In live animals, usually the bTB infection is detected through delayed hypersensitivity responses and is identified on postmortem through necropsy investigation, histopathology and bacteriology technique (Cegielski et al., 1997; Filia et al., 2016). As the tuberculosis in cattle is a universal health issue and eradication of this deadly zoonotic disease needs exact estimations of diagnostic-test performance to improve their efficacy (Nuñez-Garcia et al., 2018; Downs et al., 2019). The presence of $M$. bovis in the milk of apparently healthy milking animals is detected either on the basis of cultural examination or through molecular diagnostic procedures (Tipu et al., 2012). Bacteriological investigation encompass, the presence of acid-fast bacilli with the help of bacillus-scopy (Quinn et al., 1994; Monaghan et al., 1994) for apparent verification, the mycobacterial isolation via culture media with later identification by cultural and biochemical tests (OIE, 2009). Although, culture technique is considered the gold standard however Mycobacteria is a slow growing and needed much time for its growth. Tuberculosis can also be detected through serodiagnosis with several curbs (Daniel, 1990). As an alternative to these conventional methods, nucleic acid based techniques are more rapid, sensitive and specific means of identification of mycobacteria with some limitations (Bhattacharya et al., 2003; Tipu et al., 2012). Globally, Pakistan is one of the top 22high burden nations (HBC's), liable on behalf of $80 \%$ of total TB burden and is one of the five countries responsible for $1 / 2$ of the global TB (Metzger et al., 2010). Lots of struggles are required to boost the detection rate $(27 \%)$ because the cure rate of TB is $78 \%$ being still very low (WHO, 2004). In Pakistan, bovine tuberculosis threatens large ruminants (cattle and buffalo) in both public and private sectors (Ali et al., 2005). The diagnosis of TB at molecular level is not being used in routine and a few people have done research on this aspect. The tuberculin sensitivity test is a diagnostic tool for bovine tuberculosis (Khan et al., 2008). False positive test result may be caused by non-tuberculous mycobacteria or previous BCG vaccine. Prior BCG may result in a false-positive 
result for many years afterwards (Amin et al.,1992; Chaturvedi and Cockroft, 1992).

The prevalence of bovinetuberculosisinlarge ruminants in the central zone of Khyber Pakhtunkhwa, Pakistan has not been documented previously. On the basis of tuberculin testing, the reported prevalence of $\mathrm{bTB}$ in cattle and buffalo was $5.75 \%$ in district Peshawar (Irfan et al., 2016). Another study was conducted in district Peshawar, Khyber Pakhtunkhwa, Pakistan wherein the Mycobacterium tuberculosis (mTB) and Mycobacterium bovis (M. bovis)-were detected as $96 \%$ (288/300) and 4\% (12/300) respectively in human sputum samples through PCR showed the presence of zoonotic tuberculosis in the community (Grange et al., 1994; Irfan et al., 2018). A cross-sectional study was carried out on large ruminants and detected the occurrence and link risk factors of bTB through comparative cervical intradermal tuberculin (CCIT) test as $5.88 \%(141 / 2400)$ in five districts (Peshawar, Charsadda, Nowshera, Swabi and Mardan) of Central zone of Khyber Pakhtunkhwa, Pakistan (Ullah et al., 2019).

Keeping in view these facts, an attempt was made to estimate the prevalence of $M$. bovis infection in the dairy cattle and buffaloes in the five districts of Central zone of Khyber Pakhtunkhwa, Pakistan using PCR and conventional diagnostic methods (tuberculin testing and culture).

\section{Materials and Methods}

\section{Ethical approval}

This research study was approved by the Ethical Review Committee, The University of Agriculture Peshawar, Khyber Pakhtunkhwa (KPK), Pakistan.

\section{Sampling and methodology}

The study was designed to investigate the percent (\%) prevalence and molecular characterization of Mycobacterium in large ruminants (Cattle and Buffalo) population in five districts (Peshawar, Nowshera, Charsadda, Mardan, Swabi) of Central zone of Khyber Pakhtunkhwa, Pakistan. A total of 2400 animals (1225 cattle and 1175 buffaloes) were selected randomly from the above study area and were screened through comparative cervical intradermal injection of mammalian and avian tuberculin. During the study, 1608 large ruminants (793 cattle and 815 buffaloes) were found lactating and milk samples were collected from these lactating cattle and buffaloes (Kazwala et al., 1998, 2001) already tested through comparative cervical intradermal tuberculin (CCIT) test for further analysis. About $50 \mathrm{ml}$ of milk sample was collected aseptically in a plastic sterile container and immediately stored in ice-box and transported to the laboratory. The samples were then stored at $4-8^{\circ} \mathrm{C}$ till further analysis.

\section{Tuberculin testing}

All the selected animal tested with comparative cervical tuberculin (CCIT) test in the cervical region through proper procedure (OIE, 2009; Monaghan et al., 1994; Suleiman and Hamid, 2002; Aagaard et al., 2003; Tipu et al., 2012). Concisely, two sites about 10-12 cm apart of the cervical area were shaved with a razor and disinfected. The initial thickness of the skin in these areas were measured by using Vernier Caliper. A comparative intradermal tuberculin testing was performed by injecting a measured quantity of $0.1 \mathrm{ml}(0.5 \mathrm{mg} / \mathrm{ml})$ bovine purified protein derivative (VRI, Lahore) at one location, while the avian PPD at another location by using insulin syringe. Both the injection sites were in circled with indelible ink of different colors. After 72 hours ( $\pm 6 \mathrm{hrs}$ ), the thickness of the skin fold was measured post-inoculation. The difference between the original skin thickness and the thickness after injecting tuberculin was calculated. We classified the avian and mammalian on the basis of skin thickness as negative and positive. Skin thickness less than $3 \mathrm{~mm}$ in diameter mean a negative response, skin thickness from $3-3.9 \mathrm{~mm}$ in diameter shows unsure cases while skin thickness with $4 \mathrm{~mm}$ or more than $4 \mathrm{~mm}$ depict the animal positive for tuberculosis. Similarly, irrespective of skin thickness, edema and swelling at injection site was considered positive for tuberculosis.

\section{$D N A$ extraction and polymerase chain Reaction (PCR)}

The processing of milk samples and DNA isolation was carried out using QIAMP DNA mini kit USA ${ }^{\circledR}$ in the biosafety level II in the Department of Animal Health, The University of Agriculture, Peshawar. From each sample, $1 \mathrm{ml}$ milk was transferred to a labeled $1.5 \mathrm{ml}$ sterile eppendorf tubes. The cell lysis solution $(300 \mu \mathrm{l})$ was added to each sample and mixed by vortexed for 1 minutes. The sample was placed in water bath at $65^{\circ} \mathrm{C}$ for 60 minutes. Protein precipitation solution $(200 \mu \mathrm{l})$ was then added to the sample; mixed by vortexed for 1 minute. Then, the solution was centrifuged at $13000 \mathrm{rpm}$ for 15 minutes. 
The supernatant was then shifted to a new labelled $1.5 \mathrm{ml}$ eppendorf tube and the protein pellet was discarded which was left behind at the bottom. Isopropanol-100\% (300 $\mu \mathrm{l})$ was added and centrifuged at $14000 \mathrm{rpm}$ for 15 minutes. This time, the supernatant was discarded and ethanol-70\% $(300 \mu \mathrm{l})$ was added to the pellet already settled at the bottom of the eppendorf tube. Then, the solution was centrifuged at $14000 \mathrm{rpm}$ for 1 minute for proper concentration of DNA. Finally, the ethanol was carefully poured off and the DNA hydration solution $(20 \mu \mathrm{l})$ was added and mixed to pellet. The obtained solution was incubated at $65^{\circ} \mathrm{C}$ for 5 minutes. The extracted DNA from each milk samples was analyzed through agarose gel electrophoresis to confirm the presence of DNA (Mumtaz et al., 2008; Tipu et al., 2012).

The PCR protocol as adopted by Romero et al., 1999; Bhattacharya et al.,2003; Tipu et al.,2012 was followed with some modification for molecular identification of $M$. bovis in the milk samples. The detection of $M$. bovis was carried out by amplification of $500 \mathrm{bp}$ PCR product with specie-specific primers as $\mathrm{MB}-$ Forward: 5'-TCGTCCGCTGATGCAAGTGC-3' and MBReverse: 5'-CGTCCGCTGACCTCAAGAAG-3'.

The PCR was optimized and carried out in a Biorad $^{\circledR} \mathrm{T} 100^{\mathrm{TM}}$ thermal cycler with $25 \mu$ reaction volumes for each sample having $1.75 \mu \mathrm{l}$ of each forward $(\mathrm{F})$ and reverse $(\mathrm{R})$ primer, $10 \mu \mathrm{l}$ master $\operatorname{mix}(\mathrm{MM}), 3.5 \mu \mathrm{l}$ of DNA sample and $8 \mu \mathrm{l}$ double distilled water(DDW). The protocol for amplification involved denaturation, annealing, and extension steps at $95^{\circ} \mathrm{C}$ for $30 \mathrm{sec}, 55^{\circ} \mathrm{C}$ for $30 \mathrm{sec}$ and $72^{\circ} \mathrm{C}$ for 1 minute respectively. All the samples were subjected to 35 cycles before a final 5 minutes extension at $72^{\circ} \mathrm{C}$ and $500 \mathrm{bp}$ amplified products were obtained over 35 cycles. The PCR amplified products were further confirmed through gel electrophoresis.

\section{Gel electrophoresis}

A $100 \mathrm{ml} 1 \mathrm{X}$ TAE buffer was taken in a $100 \mathrm{ml}$ flask and 1.5 gram agarose (BIOLINE) was dissolved by keeping the flask in microwave oven for 1 minute and 30sec. Then, $4 \mu \mathrm{LSYBR}{ }^{\circledR}$ Soft gel stain (ThromoFisher Scientific), which help in visualization of amplified PCR product, was added to the flask before pouring into gel tray already fitted with combs. The combs were then removed when the gel become solidified and the gel tray was transferred to gel electrophoresis tray having enough $10 \mathrm{X}$ TAE buffer so that the gel tray dipped. All the PCR-products and $6 \mu 1$ DNA ladder (1000bp) was then loaded into gelwells using micropipettes and power supply of 120 volte, $500 \mathrm{~m}$ Amp was applied for 35 minutes. Finally, the gel was visualized with UV illumination and was photographed (Figure 1).

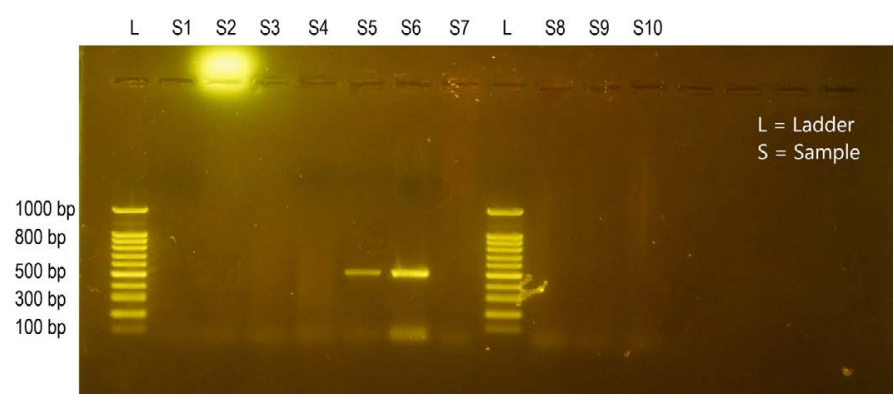

Figure 1: PCR result of bovine milk samples shorwing specie specific amplicon size of 500bp DNA of Mycobacterium bovis (M.bovis). S1-4 are $M$. bovisnegative samples and S5-6 are $M$. bovispositive samples.

\section{Conventional methods}

All the PCR positive samples were subjected to screening with conventional methods (Quinn et al., 1994). These milk samples were smeared for acid fast staining and also inoculated on Stone brink's media and incubated at $37^{\circ} \mathrm{C}$ for $6-8$ weeks. Colony characteristics and growth were recorded. Smears were made from cultures and stained by Ziehl Neelsen $(\mathrm{ZN})$ staining technique (Figure 2).

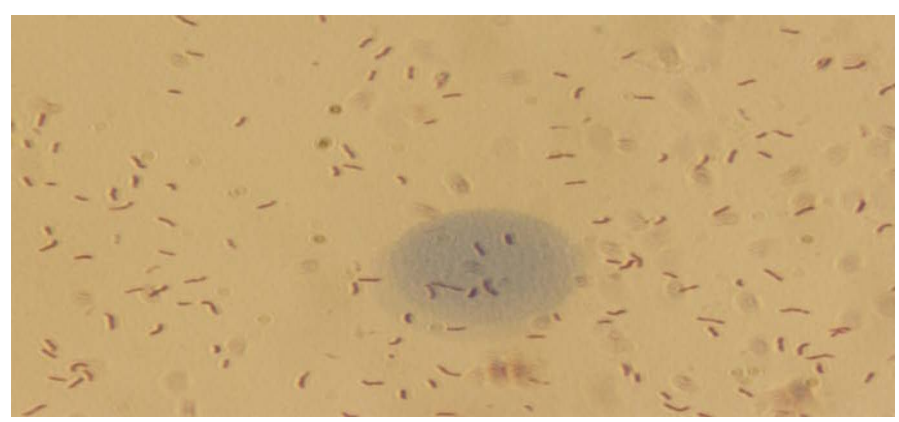

Figure 2: Ziebl-Neelsen staining showing acid-fast bacilli from milk samples.

\section{Comparison of different diagnostic techniques}

The efficacy of tuberculin test, $\mathrm{ZN}$ staining, culture test, and PCR technique for the confirmation of bovine tuberculosis were recorded and analyzed (Cegielski et al., 1997) (Figure 3).

\section{Statistical analysis}

The data was processed and analyzed statistically with SPSS (version 24.0) by applying Chi-square test with 95\% confidence intervals and the level of significance was calculated. The percent prevalence of June 2020 | Volume 36 | Issue 2 | Page 492 
the disease was presented in the form of frequencies and percentages.

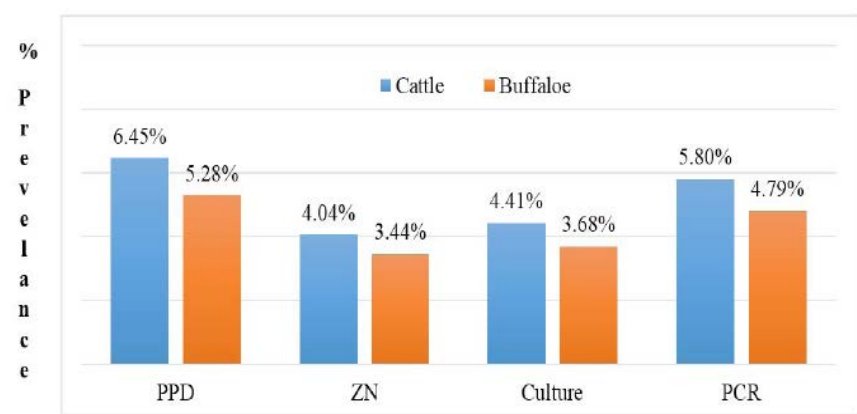

Figure 3: Efficacy of different diagnostic techniques for the confirmation of bovine tuberculosis.

\section{Results and Discussion}

A total of 2400 large ruminants were selected and tested for $M$. bovis infection through comparative cervical intradermal tuberculin test (CCIT). Out of 2400 animals tested with CCIT test, 141 were declared as bovine tuberculosis positive with a total incidence of $5.88 \%$ (95\%CI 5.68 to 6.08). District Mardan had the dominant number while district Nowshera with the minimum number of CCIT test reactors. However, the dissimilarity was nonsignificant $(\mathrm{p}=0.669)$ statistically. Two types of species were studied i.e; cattle and buffalo. During the investigation, the prevalence of bTB was recorded as $6.45 \%$ and $5.28 \%$ in cattle and buffalo population respectively. In cattle populations, outcomes of the CCIT test in five districts of KPK (Table 1) revealed that the $p$-value is 0.91 and the result is not significant at $\mathrm{p}<0.05$. Similarly, results of CCIT test in buffalo populations are shown in Table 2 in five districts of KPK wherein results showed that $\mathrm{p}$-value is 0.77 . The result is not significant at $\mathrm{p}<0.05$. Overall, the outcomes revealed that cattle were found more infected compared to buffaloes. A total of 1608 large ruminants (793 cattle and 815 buffaloes) were found lactating and milk samples from these PPD tested lactating animals were collected aseptically. The Mycobacterium was detected through ZN staining, culture and PCR. The prevalence of was found 3.73\% for acid fast bacteria through $\mathrm{ZN}$ staining while $M$. boviswas detected as $4.04 \%$ and $5.29 \%$ through culture and PCR respectively wherein chi-square statistic of the distribution of milk samples and comparison of different diagnostic techniques for the confirmation of bovine tuberculosis is 0.176 . The $p$-value is 0.981 . The result is not significant at $\mathrm{p}<0.05$ (Table 3 ).
During the investigation, the overall prevalence of CCIT test reactors for $M$. bovis infection was identified $5.28 \%$ in buffaloes and $6.45 \%$ in cattle population. A similar study was conducted by Irfan et al., 2016 and reported the bovine tuberculosis prevalence in large ruminants as $5.75 \%$ which is close to our results. In another study by Javed et al. (2008), incidence of bTB was recorded as $8.48 \%$ in buffaloes at animal experimental station, Pakistan, which is also in-line to our findings. Ghumman et al. (2013) has stated higher prevalence of bTB as $11.71 \%$ in cattle population at several dairy farms, Punjab Pakistan. On the other hand, many scientists have documented slightly lower incidence of bTB in buffaloes such as 3\% by Javed et al., 2010, 2.2\% by Javed et al., 2009 and $1.7 \%$ by Ifrahim, 2001 while several researchers have reported a little greater prevalence in buffaloes such as $9.6 \%$ by Mumtaz et al., 2008, 10.6\% by Khan et al., 2008, 11.3\% by Javed et al., 2012 and $12.72 \%$ by Khan and Khan, 2007. Animal husbandry and management practices in all the five districts of Central zone of Khyber Pakhtunkhwa, Pakistan were similar. Hence, they did not indicate major dissimilarity $(p=0.669)$ in incidence of $M$. bovis infection. A study was conducted by Donnelly and his fellows in 2016 indicated that effective farm management of bovine tuberculosis is dependent upon knowing the way of $M$. bovis transmission (Donnelly et al., 2016). The relationship was measured amongst culling and incident rate of bTB in cattle in three areas of England wherein the results showed that industry-led culling was found significantly linked with decrease in incidence rate of bTB (Downs et al., 2019). The Mycobacterium bovis infection spread to the human population by the use of unpasteurized milk reflect the zoonotic importance of the disease (Arshad et al, 2012; Olea-Popelka et al., 2017).

The Mycobacterium was detected through ZiehlNeelsen (ZN) staining, culture and PCR. The prevalence was found $3.73 \%$ for acid fast bacteria by ZN staining, $4.04 \%$ through culture and $5.29 \%$ by PCR. In India, a similar study was carried out and the prevalence of $M$. bovis infection was detected in PPD positive lactating cattle as $32.6 \%$ through PCR (Sreevatsan et al., 2000). The bTB was diagnosed through PCR on 121 isolates and all were found positive on PCR with specie-specific 500bp amplicon size showed $100 \%$ association with former microbiological characterization (Romero et al., 1999; Rodriguez et al., 1995; Figueiredo et al., 2009). 
Table 1: Prevalence of bovine tuberculosis (bTB) in cattle population on the basis of positive tuberculin test in five administrative units of Central Zone of Khyber Pakbtunkbrwa, Pakistan.

\begin{tabular}{|c|c|c|c|c|c|c|c|c|}
\hline \multirow[t]{2}{*}{ S. No } & \multirow{2}{*}{$\begin{array}{l}\text { Administrative } \\
\text { Unit }\end{array}$} & \multirow{2}{*}{$\begin{array}{l}\text { Total no of cattle } \\
\text { screened (N) }\end{array}$} & \multicolumn{2}{|c|}{$\%$ Prevalence $=(\mathrm{n} / \mathrm{N}$ X 100 $)$} & \multirow{2}{*}{$\begin{array}{l}\text { Confidence } \\
\text { Interval }\end{array}$} & \multicolumn{2}{|c|}{$95 \%$ confidence level } & \multirow[t]{2}{*}{ Chi-square } \\
\hline & & & $\mathrm{N}$ & $\%$ & & Lower & Upper & \\
\hline 1 & Peshawar & 245 & 16 & 6.53 & \pm 3.09 & 3.44 & 9.62 & \multirow[t]{6}{*}{$\mathrm{p}=0.91$} \\
\hline 2 & Nowshera & 245 & 13 & 5.31 & \pm 2.81 & 2.50 & 8.12 & \\
\hline 3 & Charsadda & 245 & 17 & 6.94 & \pm 3.18 & 3.76 & 10.12 & \\
\hline 4 & Mardan & 245 & 18 & 7.35 & \pm 3.27 & 4.08 & 10.62 & \\
\hline 5 & Swabi & 245 & 15 & 6.12 & \pm 3 & 3.12 & 9.12 & \\
\hline Total & ested & 1225 & 79 & 6.45 & \pm 1.38 & 5.07 & 7.83 & \\
\hline
\end{tabular}

N: Number of screened animals; $n$ : Number of infected animals for bTB. The $p$-value is 0.91 ; The result is not significant at $p<0.05$.

Table 2: Prevalence of bovine tuberculosis (bTB) in buffalo population on the basis of positive tuberculin test in five administrative units of Central Zone of Khyber Pakbtunkbwa, Pakistan.

\begin{tabular}{|c|c|c|c|c|c|c|c|c|}
\hline \multirow[t]{2}{*}{ S. No } & \multirow{2}{*}{$\begin{array}{l}\text { Administrative } \\
\text { unit }\end{array}$} & \multirow{2}{*}{$\begin{array}{l}\text { Total no of buffalo } \\
\text { screened }(\mathrm{N})\end{array}$} & \multicolumn{2}{|c|}{$\%$ Prevalence $=(\mathrm{n} / \mathrm{N}$ X 100) } & \multirow{2}{*}{$\begin{array}{l}\text { Confidence } \\
\text { interval }\end{array}$} & \multicolumn{2}{|c|}{$95 \%$ confidence level } & \multirow{2}{*}{$\begin{array}{l}\text { Chi- } \\
\text { square }\end{array}$} \\
\hline & & & $\mathbf{N}$ & $\%$ & & Lower & Upper & \\
\hline 1 & Peshawar & 235 & 15 & 6.38 & \pm 3.12 & 3.26 & 9.50 & $\mathrm{p}=0.77$ \\
\hline 2 & Nowshera & 235 & 10 & 4.26 & \pm 2.58 & 1.68 & 6.84 & \\
\hline 3 & Charsadda & 235 & 13 & 5.53 & \pm 2.92 & 2.61 & 8.45 & \\
\hline 4 & Mardan & 235 & 14 & 5.96 & \pm 3.03 & 2.93 & 8.99 & \\
\hline 5 & Swabi & 235 & 10 & 4.26 & \pm 2.58 & 1.68 & 6.84 & \\
\hline \multicolumn{2}{|c|}{ Total tested } & 1175 & 62 & 5.28 & \pm 1.28 & 4.00 & 6.56 & \\
\hline
\end{tabular}

N: Number of screened animals; $n$ : Number of infected animals for bTB. The p-value is 0.77; The result is not significant at $p<0.05$.

Table 3: Distribution of milk samples and comparison of different diagnostic techniques for the confirmation of bovine tuberculosis in the Central Zone of Khyber, Pakbthunkhwa, Pakistan.

\begin{tabular}{|c|c|c|c|c|c|c|c|c|c|c|c|}
\hline \multirow[t]{2}{*}{$\begin{array}{l}\text { Type of } \\
\text { animal }\end{array}$} & \multirow{2}{*}{$\begin{array}{l}\text { Total animals } \\
\text { screened with } \\
\text { PPD }\end{array}$} & \multicolumn{2}{|c|}{ Results of PPD } & \multirow{2}{*}{$\begin{array}{l}\text { Total milk } \\
\text { samples } \\
\text { collected }\end{array}$} & \multicolumn{2}{|c|}{$\begin{array}{l}\text { Result of ziehl-neels- } \\
\text { en staining }\end{array}$} & \multicolumn{2}{|c|}{ Result of culture } & \multicolumn{2}{|c|}{ Result of PCR } & \multirow[t]{2}{*}{$\begin{array}{l}\text { Chi- } \\
\text { square }\end{array}$} \\
\hline & & Positive & $\%$ & & Positive & $\%$ & Positive & $\%$ & Positive & $\%$ & \\
\hline Cattle & 1225 & 79 & 6.45 & 793 & 32 & 4.04 & 35 & 4.41 & 46 & 5.8 & $p=0.981$ \\
\hline Buffalo & 1175 & 62 & 5.28 & 815 & 28 & 3.44 & 30 & 3.68 & 39 & 4.79 & \\
\hline Total & 2400 & 141 & 5.88 & 1608 & 60 & 3.73 & 65 & 4.04 & 85 & 5.29 & \\
\hline
\end{tabular}

The chi-square statistic is 0.176 . The p-value is 0.981 . The result is not significant at $p<.05$.

The incidence of bTB was detected through comparative cervical intradermal tuberculin (CCIT) test and PCR as $2.0 \%$ and $54 \%$ respectively (Khan et al., 2012) in Lahore, Pakistan. When we compared the data of the interrelationship of different results it was concluded that tuberculosis in animal population was mainly caused by Mycobacterium bovis and was efficiently detected by the use of PCR technique as compared to other diagnostic conventional techniques. This research study specify the intense need of political/government commitment to mitigate the impact of bTB on the citizen's health by implementing control programs to address this neglected zoonotic disease (NZD) at the humananimal-ecosystem interface; also recommend the necessity for further awareness about zoonotic $\mathrm{TB}$ amongst animal farm workers; and thorough research of this specific work-related infectious and zoonotic disease is required in and around the central zone of Khyber Pakhtunkhwa (KP),Pakistan.

\section{Conclusions and Recommendations}

In Pakistan, the nature of bovine tuberculosis is endemic. Moreover, it can be concluded from the results of the study that the prevalence of CCIT test reactors for $M$. bovis infection was identified as $6.45 \%$ in cattle and $5.28 \%$ in buffalo population suggesting that cattle are more susceptible to $M$. bovis infection than buffalo. Cattles infected with $M$. bovis June 2020 | Volume 36 | Issue 2 | Page 494 
can excrete the bacillus in their milk. Close contact of human with animals, drinking raw milk and low standard of hygienic status in the animal farms are the some of the main factors that favors the spreading of bovine tuberculosis. Polymerase chain reaction is a useful and efficient technique for the detection of $M$. bovis in milk samples as compared to conventional methods. The prevalence was higher in milk samples hence transmission of bovine tuberculosis to human occur through raw (unpasteurized) milk.

1. Clinical laboratories for early diagnosis of Mycobacterium bovis infection in human and animals should be established throughout the Khyber Pakhtunkhwa (KP), Pakistan.

2. The understanding and extension education regarding the epidemiology of zoonotic tuberculosis should be recognised in the whole province.

\section{Acknowledgements}

The authors acknowledged the Higher Education Commission, Pakistan for providing financial support for this research work under HEC/NRPU Funded Project (No. 20-4718) on bovine TB.

\section{Novelty Statement}

The research and experimental work on the subject title is original and new in the field of veterinary pathology in Khyber Pakhtunkhwa, Pakistan.

\section{Author's Contributions}

All authors contributed significantly. Umar Sadique and Sultan Ayaz designed the study project, Asadullah did the research work and wrote the article, Muhammad Subhan Qureshi and Farhan Anwar Khan helped in research work and statistically analyzed the data.

\section{Conflict of interest}

The author(s) declared no potential conflicts of interest with respect to the research, authorship, and publication of this article.

\section{References}

Aagaard, C., M. Govaerts, L.M. Okkels, P. Andersen, J.M. Pollock. 2003. Genomic approach to identification of Mycobacterium bovis diagnostic antigens in cattle. J. Clin. Micro. 41:3719-3728.https://doi.org/10.1128/ JCM.41.8.3719-3728.2003

Ali, S., I.A. Khan, M.S. Mian and W. Raana. 2005. Detection of Mycobacteria from milk of cattle and buffaloes at government livestock farms. Pak. J. Agric. Sci. 42: 11-12.

Amin, S., M.A. Khan, H.A. Hashmi, M.S. Khan, I. Ahmad and M.A. Bhatti. 1992. Detection of buffalo tuberculosis by using short thermal test and isolation of causal organisms from lymph nodes. Buff. J. 8: 83-87.

Arshad, M., M. Ifrahim, M. Ashraf, S.U. Rehman and H.A. Khan. 2012. Epidemiological studies on bovine tuberculosis in buffaloes population in villages around Faisalabad. J. Plant Anim. Sci. 22(supply): 246-249.

Bhattacharya, B., K. Karak, A.G. Ghosal, A. Roy, S. Das, P. Dandapat, D. Khetawat, D.K. Mondal, S. Bhattacharaya and S. Chakarbarti. 2003. Development of a new sensitive and efficient multiplex polymerase chain reaction (PCR) for identification and differentiation of different mycobacterial species. Trop. Med. Int. Hlth. 8: 150-157. https://doi.org/10.1046/j.13653156.2003.01007.x

Broekmans, J.F., 1994. Control strategies and program management. In: Tuberculosis back to the future (eds. J.D. Intl, H. Porter and P.W.J. McAdam). John Wiley and Sons, Inc., New York., pp. 171-192.

Brooks-Pollock, E., G. Roberts and M. Keeling. 2014. A dynamic model of bovine tuberculosis spread and control in Great Britain. Nature, 511: 228-231. https://doi.org/10.1038/nature13529 Cegielski,J.P.,B.H.Devlin,A.J.Morris,J.N.Kitinya, U.P. Pulipaka, L.E. Lema, J. Lwakatare and L.B. Reller. 1997. Comparison of PCR, culture, histopathology for diagnosis of tuberculosis pericarditis. J. Clin. Microbiol., 35: 3254-3257. https://doi.org/10.1128/JCM.35.12.32543257.1997

Chaturvedi, N., and A. Cockcroft. 1992. Tuberculosis screening in health service employees: Who need chest X-rays? Occup. Med. (Lond). 42: 179-182. https://doi. org/10.1093/occmed/42.4.179

Daniel, T.M., 1990. Rapid diagnosis of tuberculosis; a selective review. J. Lab. Med. 116: 277-282.

Danker, W.M., N.J. Waecker, M.A. Essey, K. 
Moser, M. Thompson and C.E. Davis. 1993. Mycobacterium bovis infection in San Diego: A clinicoepidemiologic study of 73 patients and a historical review of a forgotton pathogen. Medicin (Baltimore). 72: 11-37. https://doi. org/10.1097/00005792-199301000-00002

Donnelly, C.A., C. Ham, S.Y.B. Jackson, K. Moyes, K. Chapman, N.G. Stratton and S.J. Cartwright. 2016. Badgers prefer cattle pasture but avoid cattle: implications for bovine tuberculosis control. Rosie Woodroffe. Ecol. Lett. 19 (10): 1201-1208. https://doi.org/10.1111/ele.12654

Downs, S.H., A. Prosser, A. Ashton, S. Ashfield, L.A. Brunton, A. Brouwer, P. Upton, Andrew Robertson, C.A. Donnelly and J.E. Parry. 2019. Assessing effects from four years of industryled badger culling in England on the incidence of bovine tuberculosis in cattle, 2013-2017. Sci. Rep. 9: 14666. https://doi.org/10.1038/s41598019-49957-6

Doyle, L.P., A.W. Gordon, D.A. Abernethy and K. Stevens. 2014. Bovine tuberculosis in Northern Ireland: risk factors associated with time from post-outbreak test to subsequent herd breakdown. Prev. Vet. Med. 116: 47-55. https:// doi.org/10.1016/j.prevetmed.2014.06.010

Figueiredo, E.E.S., F.G. Silvestre, W.N. Campos, L.V.Furlanetto,L.Medeiros, W.Lilenbaum,L.S. Fonseca, J.T. Silva and V.M.F. Paschoalin. 2009. Identification of Mycobacterium bovis isolates by a multiplex PCR. Brazilian J. Microbiol. 40: 231-233. https://doi.org/10.1590/S151783822009000200004

Filia, G., G.D. Leishangthem, V. Mahajan and A. Singh. 2016. Detection of Mycobacterium tuberculosis and Mycobacterium bovis in Sahiwal cattle from an organized farm using ante-mortem techniques. Vet. World. 9(4): 383-387. https:// doi.org/10.14202/vetworld.2016.383-387

Olea-Popelka, F., M. Adrian, P. Alejandro, S.D. Anna, M. Elizbeth, E.V. Elisabeth, F. Simona, J.S. Benjamin, D. Lucica, E.I. Ahmed, R. Mario, C. Ottorino, L. Philip and I.F. Paula. 2016. Zoonotic tuberculosis in human beings caused by Mycobacterium bovis-a call for action. Lancet Infect. Dis. S1473-3099(16): 30139-6.

Ghumman, M.A., A.W. Manzoor, S. Naz, R. Ahmad and R. Ahmad. 2013. Prevalence of tuberculosis in cattle and buffalo at various livestock farms in Punjab. Int. J. Vet. Med. Res. Rep. 2013: 1-4. https://doi. org/10.5171/2013.145084

Grange,J.M., 1998. Tuberculosis in animals "Topley and Wilson's" microbiology and microbial infections. 3(9): 411.

Grange, J.M. and M.D. Yates. 1994. Zoonotic aspects of Mycobacterium bovis infection. Vet. Microbiol., 40: 137-151. https://doi. org/10.1016/0378-1135(94)90052-3

Hussain, D. and M. Rabbani. 2000. Bovine tuberculosis a review. Pak. J. Sci., 52(3-4): 1-10.

Ifrahim, M., 2001. Epidemiological studies on tuberculosis in cattle and buffalo population in villages around Faisalabad,(Unpublished Msc (Hons) thesis, Univ. Agric., Faisalabad).

Irfan, K., M.H. Mushtaq, M.U.D. Ahmad, M.S. Khan, M. Chaudhry and U. Sadique. 2016. Risk factors associated with Mycobacterium bovis skin positivity in cattle and buffalo in Peshawar, Pakistan. Trop. Anim. Health Prod., 48: 479-485. https://doi.org/10.1007/s11250015-0976-3

Irfan, K., M.H. Mushtaq, S. Ayaz, S. Ali, A. Sheed, J. Muhammad, M.L. Sohail, H. Amanullah, I. Ahmad and Sadeeq ur Rahman. 2018. Incidence and drug resistance of zoonotic Mycobacterium bovis infection in Peshawar, Pakistan. Adv. Exp. Med. Biol. Adv. Microbiol. Infect. Dis. Publ. Health. 1057: 111-126. https://doi. org/10.1007/5584_2018_170

Jalil, H., P. Das and A. Suleman. 2003. Bovine tuberculosis in dairy animals at Lahore, threat to the public health. Metropolitan Corporation Lahore, Pakistan. 11: 1-11 htpp://priory.com/ vet/bovinetb.htm

Javed, M.T., A.F. Farooqi and H. Ullah. 2009. Epidemiological basis of bovine tuberculosis in buffaloes, Pakistan, J. Zool. Suppl. 9: 417-420.

Javed, M.T., A.L. Shahid, F.A. Farooqi, M. Akhtar, G.A. Cardenas, M. Wasiq and M. Cagiola. 2010. Risk factors associated with the presence of positive reactions in the SCCIT test in water buffalo around two cities in Punjab, Pakistan, Acta Trop., 115: 242-247. https://doi. org/10.1016/j.actatropica.2010.04.004

Javed, M.T., L. Ahmad, F. Felizianib, P. Pasqualic, M. Akhtard, M. Usman, M. Irfan, G. Severib and M. Cagiola. 2012. Analysis of some of the epidemiological risk factors affecting the prevalence of tuberculosis in buffalo at seven livestock farms in Punjab Pakistan, Asian Biomed., 6: 35-42. 
Karesh, W.B., A. Dobson, J.O. Lloyd-Smith, J. Lubroth, M.A. Dixon, M. Bennett, S. Aldrich, T. Harrington, P. Formenty, E.H. Loh, C.C. Machalaba, M.J. Thomas and D.I. Heymann. 2012. Ecology of zoonoses: natural and unnatural hostories. Lancet. 380: 1936-1945. https://doi. org/10.1016/S0140-6736(12)61678-X

Kazwala, R.R., C.J. Daborn, L.J.M. Kusiluka, S.F.H. Jiwa, J.M. Sharp and D.M. Kambarage. 1998. Isolation of Mycobacterium species from raw milk of pastoral cattle of the Southern Highlands of Tanzania. Trop. Anim. Health Prod. 30(4): 233-239. https://doi. org/10.1023/A:1005075112393

Kazwala, R.R., D.M. Kambarage, C.J. Dabom, J. Nyange, S.F. Jiwa and J.M. Sharp. 2001. Risk factors associated with the occurrence of bovine tuberculosis in cattle in the Southern Highlands of Tanzania. Vet. Res. Commun., 25: 609-614. https://doi.org/10.1023/A:1012757011524

Khan, A., Z.I. Chaudhry, A.R. Shakoori, N. Mahmood, M. Ijaz, M.Z.U. Khan, Saima, I.Jan and M.M.Ali.2012. Detection of Mycobacterium bovis in buffaloes blood through polymerase chain reaction (PCR) and tuberculin test. J. Anim. Plant Sci. 22(3 Suppl.): 237-241.

Khan, I.A. and A. Khan. 2007. Prevalence and risk factors of bovine tuberculosis in Nili-Ravi buffaloes in the Punjab, Pakistan, Ital. J. Anim. Sci., 6: 817-820. https://doi.org/10.4081/ ijas.2007.s2.817

Khan, I.A., A. Khan, A. Mubarak and S. Ali. 2008. Factors affecting prevalence of bovine tuberculosis in Nili-Ravi buffaloes. Pak. Vet. J. 28(4): 155-158.

Lahuerta-Marin, A., M. Gallagher, S. McBride, R. Skuce, F. Menzies, J. McNair, S.W.J. McDowell and A.W. Byrne. 2015. Should they stay, or should they go? Relative future risk of bovine tuberculosis for interferon-gamma test-positive cattle left on farms. Vet. Res. 46: 90. https://doi. org/10.1186/s13567-015-0242-8

Metzger, P., N.A. Baloch, G.N. Kazi and K.M. Bile. 2010. Tuberculosis control in Pakistan: Reviewing a decade of success and challenges. East. Med. Health. J. 16: S47-53. https://doi. org/10.26719/2010.16.Supp.47

Michel, A.L., B. Muller and P.D. van Helden. 2010. Mycobacterium bovis at the animal-human interface: A problem, or not? Vet. Microbiol. 140: 371-381. https://doi.org/10.1016/j. vetmic.2009.08.029

Moda, G., C.J. Daborn, J.M. Grange and O. Cosivi. 1996. The zoonotic importance of Mycobacterium bovis. Tuber. Lung Dis. 77: 103-108. https:// doi.org/10.1016/S0962-8479(96)90022-2

Monaghan, M.L., M.L. Doherty, J.D. Collins, J.F. Kazda and P.J. Quinn. 1994. The tuberculin test. Vet. Microbiol. 40: 111-124. https://doi. org/10.1016/0378-1135(94)90050-7

Mumtaz, N., Z.I. Chaudhry, N. Mahmood and A.R. Shakoori. 2008. Reliability of PCR for detection of bovine tuberculosis in Pakistan. Pak. J. Zoo. 40: 347-351.

Nuñez-Garcia, J., S.H. Downs, J.E. Parry, D.A. Abernethy, J.M. Broughan, A.R. Cameron, A.J. Cook, R. Rua-Domenech, A.V. Goodchild, J. Gunn, S.J. More, S. Rhodes, S. Rolfe, M. Sharp, P.A. Upton, H.M. Vordermeier, E. Watson, M. Welsh and M. Greiner. 2018. Meta-analyses of the sensitivity and specificity of ante-mortem and post-mortem diagnostic tests for bovine tuberculosis in the UK and Ireland. Prev. Vet. Med. 153: 94-107. https://doi.org/10.1016/j. prevetmed.2017.02.017

OIE. 2009. Manual of diagnostic tests and vaccines for terrestrial animals. World organization for animal health. Office des International Epizootics, Paris, France.

Olea-Popelka, F., A. Muwonge, A. Perera, A.S. Dean, E. Mumford, E. Erlacher-Vindel, S. Forcella, B.J. Silk, L. Ditiu, A. El-Idrissi, M. Raviglione, O.Cosivi,P.LoBue and P.I. Fujiwara. 2017. Zoonotic tuberculosis in human beings caused by Mycobacterium bovis a call for action. Lancet Infect. Dis., 17 (1): e21-e25. https://doi. org/10.1016/S1473-3099(16)30139-6

Quammen, D., 2012. Spillover. Animal Infections and the Next Human Pandemic. W.W. Norton and Company, New York, USA.

Quinn P.J., M.E. Carter, B. Markey and G.R. Carter. 1994. Mycobacterium species. Clin. Vet. Microbiol., Wolfe Publ. London. pp: 560-570.

Radostits, O.M., D.C. Blood and C.C. Gay. 2000. Veterinary medicine. A text book of diseases of cattle, sheep, pigs, goats and horses. W.B. Saunders Company Ltd. $9^{\text {th }}$ Ed., pp. 909-916.

Rodriguez, J.G., G.A. Mejia, P. Del Portillo, M.E. Patarroyo and L.A Murillo. 1995. Species identification of Mycobacterium bovis by PCR. Microbiol., 141: 2131-2138. https://doi. org/10.1099/13500872-141-9-2131 
Romero, R.E., D.L. Garzon, G.A. Mejia, W. Monroy, M.E. Patarroyo and L.A. Murillo. 1999. Identification of Mycobacterium bovis in bovine clinical samples by PCR species-specific primers. Can. J. Vet. Res., 63: 101-106.

Sreevatsan, S., J.B. Bookout, F. Ringpis, V.S. Perumaalla, T.A. Ficht, L.G. Adams, S.D. Hagius, P.H. Elzer, B.J. Bricker, G.K. Kumar, M. Rajasekhar, S. Isloor and R.R. Barathur. 2000. A Multiplex Approach to Molecular Detection of Brucella abortus and/or Mycobacterium bovis Infection in Cattle.J. Clin. Microb. 37(7): 26022610. https://doi.org/10.1128/JCM.38.7.26022610.2000

Suleiman, M.S. and M.E. Hamid. 2002. Identification of acid fast bacteria from caseous lesions in cattle in Sudan. J. Vet. Med. B., 49: 415-418. $\quad$ https://doi.org/10.1046/j.14390450.2002.00565.x

Tipu, M.Y., Z.A. Chaudhary, M. Younus and M. Rabbani. 2012. A cross sectional study of Mycobacterium bovis in dairy cattle in and arround Lahore city, Pakistan. Pak. J. Zool. 44
(2): 393-398.

Torgerson, P. and D. Torgerson. 2008. Does risk to humans justify high cost of fighting bovine TB? Nature. 455: 1029-1029. https://doi. org $/ 10.1038 / 4551029$ a

Ullah., A, U.S. Khattak, S. Ayaz, M. S. Qureshi, I. Khan, Jan, Ibadullah, I. Khattak, R. Taj, S. Nigar, N.U. Khan, M.A. Khan and M.L. Sohail. 2019. Bovine tuberculosis (bTB): Prevalence and associated risk factors in large ruminants in the Central Zone of Khyber Pakhthunkhwa, Pakistan.Pak.J.Zoo.51(1):127-133.https://doi. org/10.17582/journal.pjz/2019.51.1.127.133

WHO, 2004. Tuberculosis: Infection and transmission. Media centre, World Health Organization Fact Sheet No. 104.

Winthrop, K.L., J. Scott, D. Brown, M.T. Jay, R. Rios, S. Mase, D. Richardson, A. Edmonson, M. MacLean and J. Flood. 2005. Investigation of human contacts: A Mycobacterium bovis outbreak among cattle at a California dairy. Int. J. Tuberc. Lung. Dis. 9(7):809-813. 